\section{Turkish research council is proud of its independence}

SIR - Your recent News story "Turkish government accused of hijacking boosted science budget" (Nature 434, 1055; 2005), is unfair to the managers of the Scientific and Technical Research Council of Turkey, TUBITAK.

Your sources claim that we are being instrumental in the Turkish government's supposed "attempts to channel a growing science budget towards [its] supporters". As acting president of TUBTAK, I must say that its managers are proud of our 40-yearold council. We know that it has never been and never will be as fragile as some would like to have us fear.

Your News story accurately states: ${ }^{\alpha}$ In many countries, induding the United States, governments appoint the officials who run the institutes that distribute public science funding. Indeed, in some countries, science is funded through a government ministry, and it is only natural that governments, elected by the taxpayers, manage taxpayers' money. However, what must be absolutely beyond government control is the process of selection and management of funded research projects. This must be done, we agree, through a "robust system of peer review".

Potential appointments by the government under the proposed law (if it is passed) that are at the centre of the concerns cited in your News story are to be made to the executive board of TUBITAK: which is just that, a body in charge of administrative, not scientific, decisions. Neither the board nor TUBITAK's managers have any say whatsoever in which research projects get funded. The panels of experts in the respective scientific areas carry out evaluation and selection. How those experts are selected is also public knowledge.

Whatever the law, the responsibility of TUBITAK's professional managers is to establish an objective and transparent system for evaluating, selecting and monitoring the research projects submitted for support. Indeed, this has been our highest priority since we began work here one-and-a-half years ago. The basic structure of our new system has been open, since October 2004, to public scrutiny and critique at our website, www.tubitak.gov.tr (an English version is under construction).

Moreover, the 200 young scientists mentioned in your News story were selected through this new system, and we are prepared to account for every step of that selection process. We have processed 2,260 projects (a number that has tripled since 2003) by using 778 independent evaluators/ referees coming from over 70 universities and institutes - a highly dispersed distribution of expertise, as planned. This is only the beginning of a healthy trend. Nüket Yetis

TOBITAK, Atatīrk Bulvari 221 Kavaklidere, 06100 Ankara, Turkey

\section{No political agenda in academic bill of rights}

SIR - Your News story on our organization's academic bill of rights, "Professors bristle as states act to mould lecture content ${ }^{n}$ (Nature 434,$686 ; 2005$ ), quotes the president of a Florida faculty union who claims that the bill would amount to ${ }^{\alpha}$ a right-wing political takeover of the universities". A representative of the American Association of University Professors (AAUP) is quoted saying it would "politicize the agenda" of higher education.

Yet despite lengthy interviews with three representatives of our organization, your story failed to quote a single staff member, thus denying us the opportunity to respond.

As we repeatedly explained in interviews, the charges raised by faculty opponents and the AAUP are not based on any evidence and represent gross distortions of the bill. Neither the academic bill of rights nor any of the state legislation inspired by it are informed by a political agenda. This is clear from the text itself, which explicitly prohibits the consideration of politics in hiring and tenure decisions and forbids professors to grade students on their political or religious beliefs.

In addition, the bill's provision requiring professors to make students aware of "serious scholarly viewpoints" other than their own in class echoes the existing policies of the American Historical Association and many public universities. Fringe views, or views based on non-scientific texts such as creationism, could not be considered “serious scholarly viewpoints".

We invite readers of Nature to visit our website, www.studentsforacademicfreedom. org, and to form their own judgments.

Sara Dogan

Students for Academic Freedom, 1411 KStreet, NW, Suite 1100, Washington, DC 20005, USA

\section{Sale of public databases puts biological data at risk}

SIR — For many years, biology journals have expected data to be submitted to public databases before publication. For example, requiring a GDB accession number (or D-segment identifier) before publication of human gene mapping results enhanced the growth of GenBank. When these policies were put in place by journal publishers, they were based on the reasonable assumption that biological databases would be constantly supported and updated, and that the data would always be freely available.

With the number of biological databases growing in proportion to the growth of data, it is reasonable to expect that natural selection will occur: the best resources will thrive and others will become extinct. It is during the extinction process that accessibility to submitted data will be in question.

On 18 April 2005 a press release from Blueprint Initiative (which is the umbrella organization covering the BIND database; www.bind.ca) announced that Nature Publishing Group would «submit manuscripts containing biomolecular interaction data to the BIND database in advance of publication" and "in a manner similar to the publication of GenBank identifiers for publications containing novel sequences." But then on 2 May 2005 Blueprint announced that it would start winding down its North American operations.

To its credit, the Blueprint group claims that the BIND database will continue to be accessible and curated from its Singapore offices. However, the long-term future of BIND remains in question, and it is up to journal publishers to determine their future relationships with it.

\section{"A scenario where data could be lost, or even sold off commercially, is not impossible to imagine." - A. Jamie Cuticchia, Gregg W. Silk}

We welcome assurances from the Blueprint Initiative that BIND data will continue to be made freely available. However, the funding situation in which BIND has been placed is a warning of what could conceivably happen to databases. A scenario where data could be lost, or even sold off commercially, is not impossible to imagine.

Whether scientists will continue to ardently support journals selectively submitting pre-publication papers to databases, or requiring authors to submit data themselves prior to publication, will remain to be seen. Whatever happens to $\mathrm{BIND}$, assuring the availability and rights to the scientists' own data should remain a number-one priority of both journals and database managers.

\section{A. Jamie Cuticchia, Gregg W. Sillk}

Bioinformatics, Research Triangle Institute, 3040 Cornwallis Road, Research Triangle Park, North Carolina 27709, USA

No NPG journal insists that authors submit data to BIND in advance of publication. Some NPG journals send manuscripts to BIND shortly before publication so that accession number links can be included in the paper, but authors can choose to opt out of this system. For all other journals (including Nature) BIND curates the data after publication - Editor, Nature. 